\title{
Potensi Konsorsium Sampel Air Pelabuhan Kamal dan Bittern dalam Mendegradasi Solar
}

\author{
Harfatia Chandra Puspita Sari, Haryo Triajie*, Abdus Salam Junaedi
}

Departemen Kelautan dan Perikanan, Fakultas Pertanian, Universitas Trunojoyo Madura J. Raya Telang, PO BOX 2 Kamal, Bangkalan, Jawa Timur 69162 Indonesia

Email: haryotriajie@trunojoyo.ac.id

\section{Abstract \\ Potential Consortium of Water Samples Kamal Harbor and Bittern in Degrading Diesel Fuel}

Biodegradation is an alternative in overcoming oil pollution biologically. Utilization of bacteria obtained from contaminated (indigenous) areas is known to be more effective in the degradation process. This study aims to determine the characteristics of indigenous bacteria that have been isolated from Kamal harbor water samples, and the consortium will be compared with the consortium of bacteria isolated from salt waste water (bittern) samples to determine their ability to degrade diesel pollutants. The method used in this research is the enrichment method, to obtain bacterial isolates. The consortium was treated with solar concentrations of $1 \%, 1.5 \%, 2 \%, 2.5 \%$, and $3 \%$. The results showed that 4 types of bacteria were obtained (BI. 1, BI.2, BI.3, and BI. 4) from Kamal harbor waters with different macroscopic and microscopic characteristics. The highest \%total petroleum hydrocarbons (TPH) reduction by the indigenous consortium was in the $3 \%$ diesel treatment with a value of 3.87, while in the bittern consortium there was $2.5 \%$ diesel treatment with a value of 3.34.

Keywords : bittern, degradation, indigenous, diesel fuel

\begin{abstract}
Abstrak
Biodegradasi merupakan salah satu alternatif dalam menanggulangi pencemaran minyak secara biologis. Pemanfaatan bakteri yang diperoleh dari area pencemaran (indigenous)diketahui akan lebih efektif dalam proses degradasi. Penelitian ini bertujuan untuk mengetahui karakteristik bakteri yang berhasil diisolasi dari sampel air pelabuhan kamal, dan konsorsiumnya akan dibandingkan dengan konsorsium bakteri yang berhasil diisolasi dari sampel air limbah garam (bittern) guna mengetahui kemampuannya dalam mendegradasi bahan pencemar solar. Metode yang digunakan dalam penelitian yaitu metode enrichment, untuk memperoleh isolat bakteri. Konsorsium diberi perlakuan dengan konsentrasi solar 1\%, 1,5\%,2\%, 2,5\%, dan 3\%. Hasli penelitian menunjukkan diperoleh 4 jenis bakteri (BI.1, BI.2, BI.3, dan Bl.4) dari perairan pelabuhan kamal dengan karakteristik makroskopis dan mikroskopis yang berbeda-beda. Penurunan \%total petroleum hidrokarbon (TPH) tertinggi oleh konsorsium indigenous terdapat pada perlakuan solar $3 \%$ dengan nilai sebesar 3,87, sedangkan pada konsorsium bittern terdapat pada perlakuan solar $2,5 \%$ dengan nilai sebesar 3,34.
\end{abstract}

Kata kunci : bittern, degradasi, indigenous, solar

\section{PENDAHULUAN}

Pelabuhan menjadi salah satu area
yang paling berpotensi mengalami
pencemaran air yang disebabkan oleh

minyak solar, hal ini dapat terjadi karena di pelabuhan terdapat aktivitas seperti penyeberangan, bongkar muat tengah laut, dan perbaikan atau perawatan kapal (docking). Menurut Utomo et al., (2013) 
pencemaran di Pelabuhan dapat disebabkan oleh tumpahan minyak solar yang menjadi bahan bakar kapal. Pencemaran minyak bumi di laut menjadi permasalahan yang serius karena peristiwa ini bersifat destruktif bagi biota laut. Biota laut akan mengalami dampak pencemaran baik secara langsung maupun tidak langsung. Penanggulangan terhadap pencemaran minyak dapat dilakukan baik secara fisika, kimia, dan biologi. Penanggulangan secara biologi dilakukan dengan teknologi bioremediasi, Berdasarkan aspek profitabel teknologi ini memiliki kelebihan yakni ramah lingkungan, murah, dan fleksibel (Sulistyono, 2013). Salah satu teknik dalam bioremediasi yaitu biodegradasi menjadi salah satu alternatif untuk menanggulangi pencemaran minyak secara biologis dengan memanfaatkan mikroorganisme.

Penggunaan bakteri sebagai agen pendegradasi akan lebih efektif apabila bakteri tersebut didapatkan dari area pencemaran. Menurut Ismail et al., (2015) dengan memanfaatkan sifat indigenous ataupun extraneous mikroba mampu mengatasi pencemaran hidrokarbon. Beberapa penulis telah melaporkan terkait kemampuan bakteri indigenous dalam mendegradasi minyak solar (Hasyimuddin et al., 2016, Andhini et al., 2018, Puspitasari et al., 2020). Namun, penelitian terkait pemanfaatan bakteri di Perairan Pelabuhan Kamal belum pernah dilakukan. Selain itu, informasi terkait pemanfaatan bakteri nonindigenous yang diisolasi dari air limbah garam (bittern) dalam menguraikan komponen pencemaran hidrokarbon belum banyak diungkap. Berdasarkan latar belakang diatas, maka perlu dilakukan penelitian terkait beberapa bakteri indigenous dan non-indegenous yang potensial untuk menguraikan komponen pencemaran hidrokarbon.

Penelitian ini bertujuan untuk mengetahui karakteristik bakteri yang berhasil diisolasi dari sampel air pelabuhan kamal dan konsorsiumnya akan dibandingkan dengan konsorsium bakteri yang berhasil diisolasi dari sampel air limbah garam (bittern) sebagai bakteri non-indigenous guna mengetahui kemampuannya dalam mendegradasi bahan pencemar solar.

\section{MATERI DAN METODE}

Penelitian ini dilaksanakan pada Bulan Oktober hingga Desember 2020. Stasiun pengambilan sampel dilakukan di area Pelabuhan Kamal. Pelabuhan kamal digunakan sebagai penghubung antara Pulau Madura dan Pulau Jawa dan memiliki letak geografis pada $7^{\circ} 10^{\prime} 29.4^{\prime \prime} S$ $112^{\circ} 43^{\prime} 18.4^{\prime \prime}$. Pengambilan sampel dan pengukuran kualitas air dilakukan pada stasiun yang telah ditentukan. Stasiun pengambilan sampel dapat dilihat pada Gambar 1.

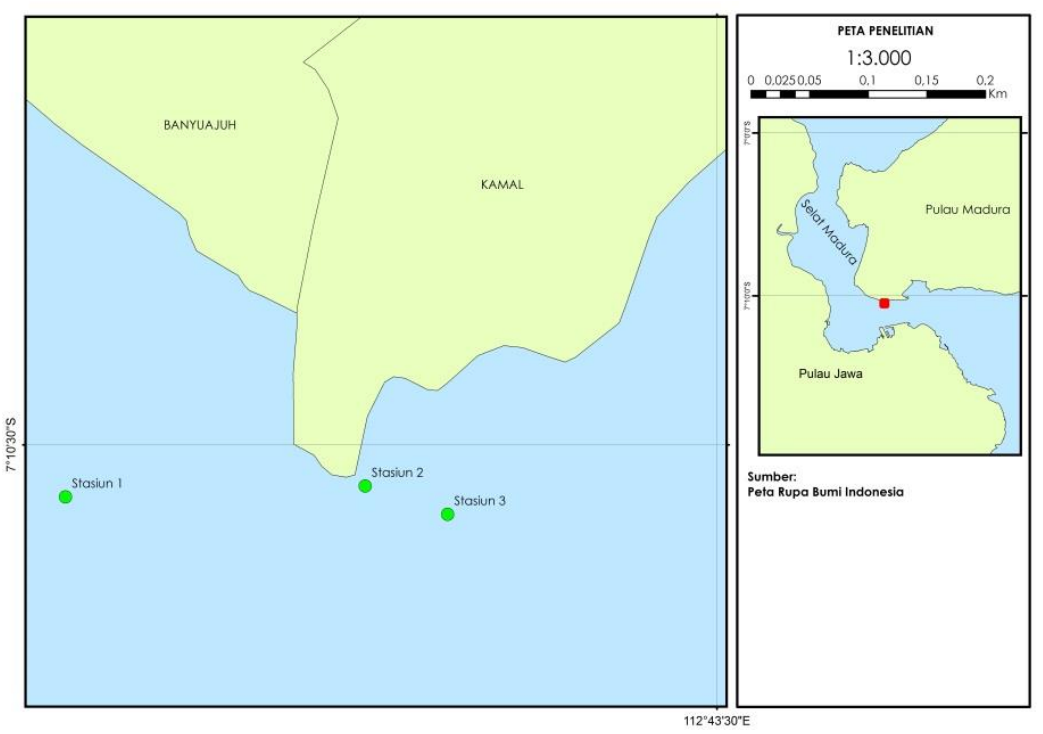

Gambar 1. Lokasi Penelitian 
Sterilisasi peralatan yang terbuat dari aluminium seperti jarum ose dilakukan dengan pemijaran. Sedangkan peralatan glass dicuci dan dikeringkan menggunakan tissue, kemudian dibungkus menggunakan kertas dan dimasukkan ke dalam plastik. Sterilisasi alat tersebut dilakukan dengan menggunakan autoklaf selama 15 menit, pada suhu $121^{\circ} \mathrm{C}$ dengan tekanan $1 \mathrm{~atm}$. Pembuatan media cair Stone Mineral Salt Solution Extract Yeast (SMSSe) dilakukan dengan menimbang $0,5 \mathrm{~g} \mathrm{CaCO}_{3}, 0,25 \mathrm{~g}$ $\mathrm{NH}_{4} \mathrm{NO}_{3}, 0,1 \mathrm{~g} \mathrm{Na} \mathrm{HPO}_{4} .7 \mathrm{H}_{2} \mathrm{O}, 0,05 \mathrm{~g} \mathrm{KH}_{2} \mathrm{PO}_{4}$, $0,05 \mathrm{~g} \mathrm{MgSO}_{4} .7 \mathrm{H}_{2} \mathrm{O}, 0,02 \mathrm{~g} \mathrm{MnCl}_{2} .7 \mathrm{H}_{2} \mathrm{O}$ dan ditambahkan dengan ekstrak ragi sebanyak $0,01 \%(\mathrm{~b} / \mathrm{v})$ atau sebanding dengan $0,02 \mathrm{~g}$ yang dilarutkan dalam $200 \mathrm{~mL}$ air laut steril. Pembuatan media padat Stone Mineral Salt Solution Extract Yeast (SMSSe) dilakukan dengan menambahkan $2 \%$ bacto agar sebagai pemadat dalam media. Selain itu, ditambahkan minyak solar sebanyak $2 \%(b / v)$ dalam media yang bertujuan sebagai sumber karbon (Nurjanah, 2020).

Pengambilan sampel dilakukan pada tiga stastiun yang telah ditentukan dengan 3 kali pengulangan. Stasiun terletak di pelabuhan kamal yang merupakan area penyeberangan kapal. Metode yang digunakan dalam pengambilan sampel yaitu metode purposive sampling (Puspitasari et al., 2020). Sampel air laut diambil menggunakan botol sampel $100 \mathrm{~mL}$ steril dengan cara memasukkan botol hingga kedalaman $15 \mathrm{~cm}$ dari permukaan air, dan ditutup dengan posisi botol yang masih berada di kolom air (Mijaya et al., 2019). Botol sampel kemudian disimpan dalam kondisi dingin pada coolbox. Pengukuran beberapa parameter kualitas air seperti salinitas, suhu, $\mathrm{pH}$, dan dissolved oxygen (DO) juga dilakukan pada lokasi pengambilan sampel air laut.

Isolasi dilakukan dengan cara memasukkan sumber isolat yaitu air laut sebesar 2\% (b/v) ke dalam media SMSSe cair yang telah diberi solar sebesar $2 \%(b / v)$, kemudian diinkubasi pada suhu ruang diatas rotary shaker dengan kecepatan $120 \mathrm{rpm}$ selama 3 hari. Isolasi dilakukan dengan metode pengenceran hingga $10^{-5}$ menggunakan $\mathrm{NaCl}$ fisiologis steril (Hasyimuddin et al., 2016). Tiga pengenceran terakhir yaitu $10^{-3}, 10^{-4}, 10^{-5}$ diambil sebanyak $1 \mathrm{~mL}$ untuk dibiakkan di atas media Stone Mineral Salt Solution Extract Yeast (SMSSe) yang mengandung solar sebesar $2 \%(\mathrm{~b} / \mathrm{v})$ dan bacto agar sebesar $2 \%$. Isolasi bakteri pada media padat dilakukan dengan metode cawan sebar (spread plate) (Nurjanah, 2020). Inkubasi dilakukan pada suhu $35^{\circ} \mathrm{C}$ selama $2 \times 24$ jam. Setiap koloni yang tumbuh dengan morfologi yang berbeda dibiakkan kembali dengan metode gores (streak plate) pada media serupa untuk memperoleh koloni tunggal. Karakterisasi bakteri dilakukan dengan pengamatan secara makroskopis meliputi bentuk, warna, tepian (margin), dan elevasi, dan mikroskopis meliputi pewarnaan gram dan uji biokimiawi (uji katalase, motilitas, dan sitrat).

Pembuatan suspensi isolat bakteri 10-8 $\mathrm{sel} / \mathrm{mL}$ dilakukan dengan mengambil isolat murni menggunkan jarum ose steril sebanyak 1-2 ose, kemudian isolat tersebut dimasukkan dalam tabung reaksi yang telah berisi larutan $\mathrm{NaCl}$ fisiologis $0,85 \%$. Kekeruhan (turbidity) campuran tersebut dipadankan dengan 0.5 McFarland Standard (Nababan, 2008).

\section{Uji Potensi Konsorsium dalam Mendegradasi Solar}

Uji potensi konsorsium dilakukan dengan mengambil sebanyak $0,5 \mathrm{~mL}$ konsorsium sejumlah $10^{-5} \mathrm{sel} / \mathrm{mL}$, kemudian konsorsium ditambahkan dalam media Stone Mineral Salt Solution Extract Yeast (SMSSe) cair sebanyak $75 \mathrm{~mL}$ yang telah diberi solar dengan konsentrasi $1 \%(0,75 \mathrm{~mL}), 1,5 \%(1,1$ $\mathrm{mL}), 2 \%(1,5 \mathrm{~mL}), 2,5 \%$ (1,9 mL), dan $3 \%(2,3$ $\mathrm{mL}$ ) secara terpisah. Selain menggunakan konsorsium (beberapa isolat bakteri) dari sampel air pelabuhan kamal juga dilakukan perlakuan dengan menggunakan konsorsium (beberapa isolat bakteri) dari sampel air limbah garam (bittern) dan kontrol (perlakuan tanpa isolat). Kultur diinkubasi pada suhu ruang dan dibuncang di atas rotary shaker dengan kecepatan $120 \mathrm{rpm}$ (Nababan, 2008). Menurut Ismail et al., (2015), inkubasi dilakukan selama $7 \times 24$ jam, yaitu selama masa inkubasi pertumbuhan isolat diukur berdasarkan nilai optical density (OD) dengan menggunakan spektrofotometer 
pada panjang gelombang $600 \mathrm{~nm}$. Pengukuran kepadatan bakteri pada penelitian ini dilakukan pada hari ke-0, 3, 5, dan 7. Selain itu, perubahan $\mathrm{pH}$ diukur bersamaan dengan pengukuran nilai Total Petroleum Hidrokarbon (TPH) yang dilakukan pada hari ke-0 dan hari ke-7 masa inkubasi.

Total Petroleum Hidrokarbon (TPH) dianalisis secara gravimetri dengan memasukkan sampel sebanyak $10 \mathrm{~mL}$ media Stone Mineral Salt Solution Extract Yeast (SMSSe) yang mengandung solar hasil perlakuan ke dalam corong pisah. Langkah selanjutnya yaitu menambahkan $15 \mathrm{~mL} \mathrm{n}$ heksana hasil pemurnian dengan destilasi bertingkat pada suhu $60^{\circ} \mathrm{C}$, kemudian campuran dikocok selama 5 menit dan diamkan hingga n-heksana terpisah. Kemudian akan terbentuk tiga lapisan yaitu minyak, n-heksana, dan air. Bagian air dibuang, sedangkan minyak dan n-heksana dilakukan penyaringan menggunakan kertas saring yang telah diolesi dengan $\pm 0,5 \mathrm{~g}$ $\mathrm{Na}_{2} \mathrm{SO}_{4}$ ke dalam gelas beker yang telah ditimbang. Gelas beker tersebut dipanaskan pada suhu $60^{\circ} \mathrm{C}$ (sesuai dengan titik didih $\mathrm{n}$ heksana) hingga $\mathrm{n}$-heksana dan air habis karena menguap, sehingga yang tersisa dalam gelas beker hanya minyak. Gelas beker tersebut diangkat dan didiamkan hingga dingin, kemudian dilakukan penimbangan dan pencatatan beratnya (Bhaktinagara et al., 2015). Rumus yang digunakan untuk menghitung \%TPH yaitu:

$$
\% \text { TPH }=\frac{\text { Berat residu }}{\text { Berat sampel }} \times 100 \%
$$

\section{HASIL DAN PEMBAHASAN}

Hasil penelitian menunjukkan bahwa kualitas air di perairan pelabuhan kamal diperoleh nilai rata-rata yang disajikan pada Tabel 1. Nilai pH optimum untuk kehidupan mikroba dalam air yaitu $6,0-8,0$, hal ini menunjukkan bahwa mikroba dapat hidup di perairan pelabuhan kamal. Nilai oksigen terlarut atau dissolved oxygen (DO) di perairan pelabuhan kamal berkisar antara 7,96-8,97 dan salinitas sebesar 33 ppt. Salinitas di perairan dapat menyebabkan waktu generasi bakteri menjadi panjang, selain itu dapat merubah morfologis dan fisiologis bakteri. Bakteri pada lokasi penelitian tergolong bakteri mesofilik, hal tersebut disebabkan karena bakteri mesofilik memiliki suhu pertumbuhan yang optimum pada $30-40^{\circ} \mathrm{C}$ (Mudatsir, 2007).

\section{Karakteristik Isolat Bakteri di Perairan Pelabuhan Kamal}

Hasil penelitian menunjukkan bahwa isolat bakteri yang diperoleh dari perairan pelabuhan kamal memiliki karakteristik makroskopis dan mikroskopis yang berbeda. Menurut Junaedi et al., (2020) perbedaan spesies bakteri dapat ditunjukkan dengan adanya karakteristik koloni bakteri yang berbeda-beda. Hasil karakterisasi bakteri secara makroskopis disajikan pada Tabel 2. Menurut Safrida et al., (2012) perbedaan bentuk koloni bakteri dipengaruhi oleh beberapa faktor meliputi umur, faktor lingkungan (biotik dan abiotik), faktor makanan (medium pertumbuhan), dan suhu. Hasyimuddin et al., (2016) juga mengemukakan bahwa adaptasi bakteri terhadap lingkungannya akan mempengaruhi bentuk morfologi dan struktur anatomi bakteri untuk bertahan hidup. Hasil karakteristik mikroskopis bakteri disajikan pada Tabel 3. Bakteri jenis gram negatif ditandai dengan warna merah sedangkan jenis gram positif ditandai dengan warna ungu pada koloni bakteri saat diamati di bawah miskroskop. Menurut Sopiah (2011) bakteri gram negatif mampu menyerap larutan kristal violet secara maksimal, sedangkan bakteri gram negatif tidak mampu mempertahankan warna dari larutan kristal violet, sehingga saat diberikan safranin sebagai warna pebanding sel bakteri menunjukkan warna merah.

Tabel 1. Kualitas air di Pelabuhan Kamal

\begin{tabular}{ccccc}
\hline Stasiun & $\mathrm{pH}$ & Dissolved oxygen (DO) & Salinitas & Suhu \\
\hline 1 & 7,34 & 8,97 & 33 & 30,1 \\
2 & 7,31 & 8,14 & 33 & 30,3 \\
3 & 7,49 & 7,96 & 33 & 30,5 \\
\hline
\end{tabular}


Tabel 2. Karakteristik Makroskopis Bakteri

\begin{tabular}{ccccc}
\hline Karakter makroskopis & Bl.1 & Bl.2 & Bl.3 & Bl.4 \\
\hline Warna & Putih & Putih & Putih & Putih \\
Bentuk & Circular & Irreguler & Irreguler & Rhizoid \\
Tepian & Smooth & Lobate & Irreguler & Rhizoid \\
Elevasi & Flat & Convex & Flat & Flat \\
Permukaan & Halus & Kasar & Kasar & Kasar \\
Ukuran & Kecil & Kecil & Besar & Kecil \\
Diameter & $4,4 \mathrm{~mm}$ & $5,45 \mathrm{~mm}$ & $6,8 \mathrm{~mm}$ & $5,6 \mathrm{~mm}$ \\
\hline
\end{tabular}

Tabel 3. Karakteristik Mikroskopis Bakteri

\begin{tabular}{ccccccc}
\hline \multirow{2}{*}{ Jenis bakteri } & \multicolumn{2}{c}{ Pewarnaan gram } & Sitrat & \multirow{2}{*}{ Katalase } & Motilitas \\
\cline { 2 - 4 } & Gram & Bentuk & Butt/Slant & & & + \\
\hline BI.1 & Negatif & Bacil & $-/+$ & - & + \\
BI.2 & Negatif & Coccus & $-/-$ & + & + \\
BI.3 & Positif & Bacil & $-/-$ & + & + \\
BI.4 & Negatif & Coccus & $-/-$ & + & + \\
\hline
\end{tabular}

Hasil positif pada uji sitrat menunjukkan bahwa adanya pemanfaatan sitrat oleh isolat bakteri yang ditandai dengan perubahan warna media dari hijau menjadi biru. Menurut Ismail et al., (2015) perubahan warna biru pada media uji menandakan bahwa isolat bakteri dapat memanfaatkan media sitrat sebagai sumber karbon. Hasil negatif pada uji katalase ditandai dengan tidak terbentuknya gelembung pada kaca preparat setelah diberikan larutan $\mathrm{H}_{2} \mathrm{O}_{2} 3 \%$, sedangkan hasil positif ditandai dengan terbentuknya gelembung pada saat pengujian. Menurut Wahyuni et al., (2018) hasil positif dalam uji katalase ditandai dengan terdapatnya bakteri yang mampu menghasilkan enzim katalase untuk mengkatalisa pemecahan hidrogen peroksida $\left(\mathrm{H}_{2} \mathrm{O}_{2}\right)$ menjadi senyawa $\mathrm{H}_{2} \mathrm{O}$ dan $\mathrm{O}_{2}$. Uji motilitas terhadap semua isolat bakteri menunjukkan hasil yang positif atau bersifat motil. Hal ini ditandai dengan adanya jejak pergerakan bakteri di sekitar tusukan dan terbentuknya pelikel pada permukaan media. Menurut Elvira et al., (2016) pelebaran bakteri pada permukaan media menandakan jika bakteri tersebut memiliki flagella.

\section{Nilai optical density (OD) selama Masa Inkubasi}

Hasil pengukuran optical density (OD) terhadap perlakuan kontrol, konsorsium indigenous, dan konsorsium bittern dapat dilihat pada Gambar 2. Gambar 2 (a) menunjukkan bahwa nilai optical density mengalami perbedaan sejak awal masa inkubasi hari ke-0. Fluktuasi nilai optical density (OD) tersebut diduga disebabkan karena media yang telah ditambahkan solar dengan konsentrasi yang berbeda tidak homogen. Selain itu, perlakuan kontrol pada masa inkubasi hari ke-3 diduga mengalami kontaminasi. Hal ini sesuai dengan hasil penelitian Ismail et al., (2015) bahwa pada perlakuan kontrol negatif (tanpa isolat bakteri) memungkinkan terjadinya kontaminasi. Kontaminasi mulai terjadi pada waktu inkubasi 3 hari yang ditandai dengan meningkatnya nilai optical density (OD).

Gambar 2 (b) menunjukkan bahwa pada masa inkubasi hari ke-3 semua perlakuan konsentrasi solar mengalami penurunan nilai optical density (OD). Menurut Mijaya et al., (2019), pada awal masa 
inkubasi jumlah bakteri yang tumbuh sedikit, hal ini disebabkan karena bakteri masih dalam fase adaptasi dengan substratnya. Fluktuasi terjadi pada masa inkubasi hari ke-5, perlakuan konsentrasi solar $1,5 \%, 2 \%$, dan $3 \%$ mengalami fase eksponensial yang ditandai dengan kenaikan nilai optical density (OD). Penambahan jumlah bakteri menandakan jika bakteri dapat memenuhi sumber nutrinya melalui pemanfaatan substrat yang ada. Menurut Nasikhin dan Maya (2013) pertumbuhan bakteri pada media menandakan bahwa isolat bakteri tidak hanya mampu memanfaatkan yeast extract, namun juga mampu memanfaatkan solar sebagai sumber karbon organik. Perlakuan konsentrasi solar $1 \%$ dan $2,5 \%$ nilai optical density (OD) mengalami penurunan. Hal tersebut menunjukkan bahwa pada perlakuan konsentrasi solar $1 \%$ dan $2,5 \%$ konsorsium membutuhkan waktu adaptasi yang lebih lama.
Gambar 2 (c) menunjukkan bahwa pada masa inkubasi hari ke-7 pada perlakuan konsentrasi solar $1,5 \%$ telah mengalami fase kemunduran (death phase). Namun, pada perlakuan konsentrasi solar 1\%, $2 \%, 2,5 \%$, dan $3 \%$ masih terjadi kenaikan nilai optical density. Kenaikan nilai optical density (OD) pada akhir masa inkubasi hari ke-7 menunjukkan bahwa masih banyak bakteri yang hidup. Hal ini menandakan bahwa waktu pertumbuhan yang dimiliki oleh bakteri tersebut panjang. Selain itu, penurunan jumlah bakteri yang ditandai dengan penurunan optical density (OD) disebabkan karena pada media pertumbuhan terjadi akumulasi bahan beracun (toxic) dan penurunan nutrien sehingga jumlahnya yang terbatas (Ismail et al., 2015). Menurut Puspitasari et al., (2020) penurunan jumlah sel bakteri pada akhir masa inkubasi disebabkan karena berkurangnya nutrien berupa $\mathrm{N}$ dan $\mathrm{P}$ yang terkandung dalam media.

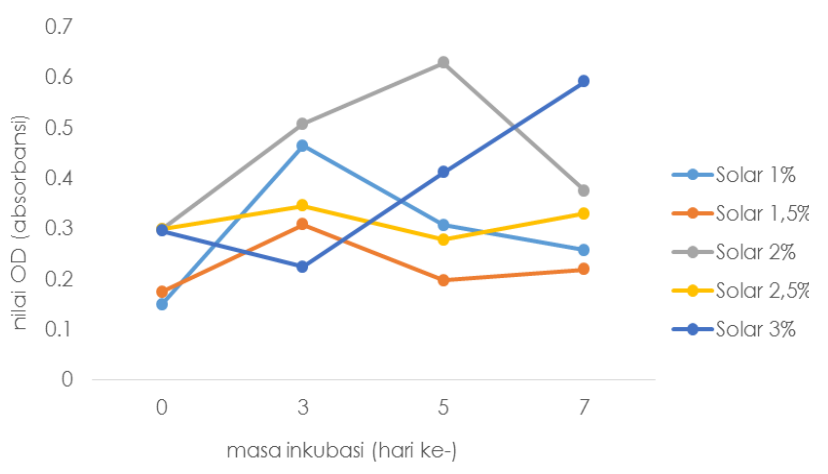

(a)

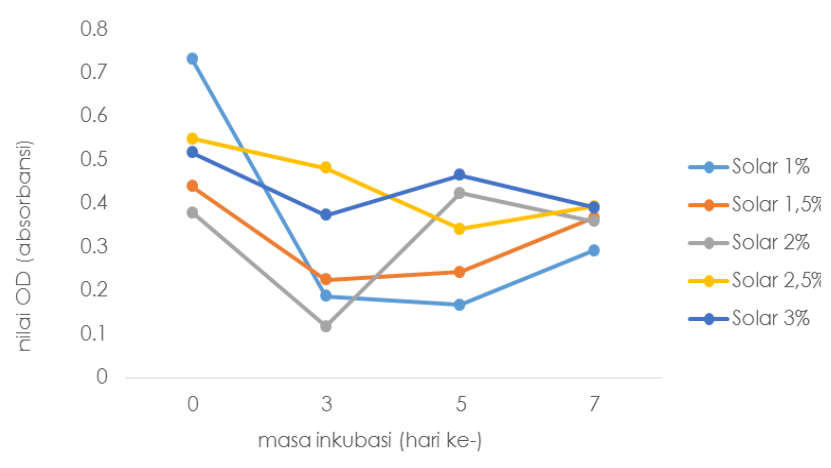

(b)

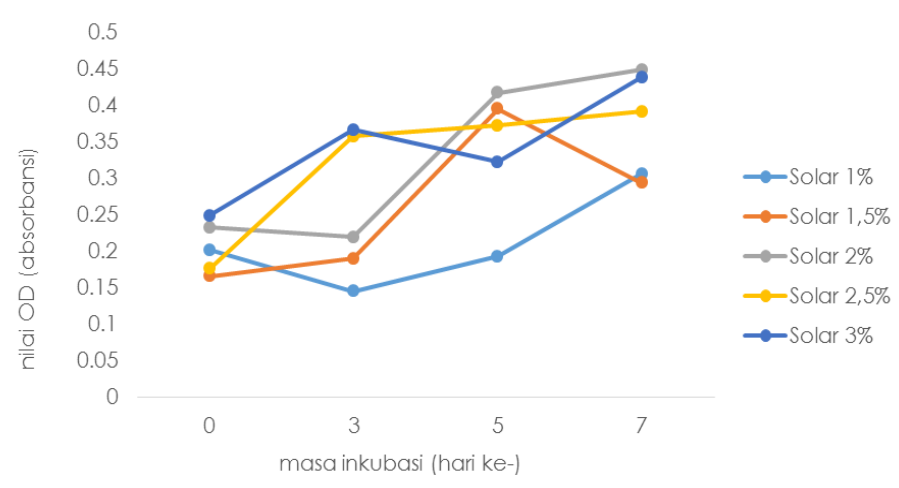

(c)

Gambar 2. Nilai optical density (OD) (a). Kontrol (b). Konsorsium Indigenous (c).Konsorsium Bittern 
Menurut Nugroho (2007) bahwa proses degradasi atau perombakan oleh konsorsium bakteri (campuran beberapa isolat bakteri) terhadap senyawa hidrokarbon ditandai dengan kurva pertumbuhan yang fluktuatif. Fluktuasi kurva pertumbuhan konsorsium diakibatkan oleh perubahan dominansi bakteri pada media pertumbuhan. Pertumbuhan konsorsium bakteri tidak selalu meningkat meskipun dengan penambahan solar sebagai sumber karbon. Hal tersebut disebabkan karena jenis bakteri yang mendominansi sulit dalam mendegradasikan komposisi hidrokarbon. Selain itu, proses degradasi ditandai dengan perubahan nilai $\mathrm{pH}$ selama masa inkubasi. Nilai $\mathrm{pH}$ pada perlakuan kontrol, konsorsium indigenous, dan konsorsium bittern saat masa inkubasi hari ke-0 berkisar antara 6,0-6,5. Nilai $\mathrm{pH}$ menunjukkan penurunan pada masa inkubasi hari ke-7 berkisar antara 5,4-5,9. Penurunan nilai $\mathrm{pH}$ tersebut diakibatkan oleh bakteri yang melakukan aktivitas metabolisme bakteri mengkibatkan nilai $\mathrm{pH}$ menurun. Penurunan nilai pH pada media tidak terlalu besar, hal ini disebabkan karena adanya senyawa $\mathrm{KH}_{2} \mathrm{PO}_{4}$ sebagai larutan penyangga yang terkandung dalam media. Menurut Ristiati et al. (2016) bahwa reaksi kimia yang terjadi di dalam media berupa pertukaran ion $\mathrm{K}^{+}$dari dalam sel dengan ion $\mathrm{H}^{+}$yang terdapat di lingkungan menyebabkan penurunan nilai $\mathrm{pH}$ media.

\section{Nilai \% Total Petroleum Hidrokarbon (TPH) selama Masa Inkubasi}

Penurunan nilai \% Total Petroleum Hidrokarbon (TPH) oleh konsorsium indigenous pada akhir masa inkubasi hari ke-7 dapat dilihat pada Gambar 3 (b). Penurunan tersebut disebabkan karena isolat bakteri dalam bentuk konsorsium yang ditambahkan sebagai perlakuan berasal dari area pelabuhan yang tercemar minyak solar. Penggunaan bakteri sebagai agen pendegrasi dapat diperoleh dari area yang mengandung hidrokarbon (Mijaya et al., 2019). Sedangkan peningkatan dan penurunan \% Total Petroleum Hidrokarbon (TPH) oleh konsorsium bittern pada akhir masa inkubasi hari ke-7 (Gambar 3 (c))diduga disebabkan karena isolat bakteri dalam bentuk konsorsium yang ditambahkan dalam media berasal dari lingkungan yang tidak tercemar oleh minyak solar, sehingga konsorsium tersebut tidak mampu melakukan proses degradasi secara maksimal. Selain itu, penyebab lainnya adalah saat analisis \% Total Petroleum Hidrokarbon (TPH) jumlah solar yang terambil dari tiap perlakuan konsentrasi solar $(1 \%, 1,5 \%, 2 \%, 2,5 \%$, dan $3 \%)$ tidak selalu sama. Hal tersebut sesuai dengan pernyataan Hafiluddin (2011) bahwa fluktuasi kadar minyak selama masa inkubasi diduga disebabkan karena saat analisa sampel yang terambil kurang homogen.

Proses degradasi akan seiring dengan peningkatan kekeruhan media. Kekeruhan media pada penelitian ini mulai terjadi pada masa inkubasi hari ke-3. Hal tersebut sesuai dengan pernyataan Prayitno et al., (2010) bahwa tingkat kekeruhan media yang disebabkan karena adanya minyak terlarut menjadi salah satu cara untuk mengetahui kemampuan degradasi oleh bakteri. Peningkatan kekeruhan media seiring dengan berkurangnya lapisan minyak solar pada permukaan media. Menurut Charlena et al., (2011), lapisan solar yang berada pada permukaan media akan terpecah menjadi butiran-butiran-butiran kecil, hal ini diakibatkan oleh keberadaan biosurfaktan yang dihasilkan oleh isolat bakteri. Kemampuan degradasi minyak solar oleh konsorsium bakteri disebabkan karena adanya enzim yang dihasilkan bakteri tersebut, sehingga senyawa organik kompleks dapat dipecah menjadi senyawa sederhana sehingga dapat diserap oleh bakteri dan dijadikan sebagai nutrisi untuk kehidupannya (Yolantika et al., 2015). Enzim monooksigenase dan enzim dioksigenase merupakan enzim yang dihasilkan oleh bakteri yang memiliki kemampuan untuk membuka ikatan karbon pada cincin aromatik dan menghasilkan alkohol primer. Enzim dioksigenase yang dihasilkan oleh bakteri akan mendegradasikan PAH sehingga terbentuk cis-hidrodiol. Senyawa cis-hidrodiol akan membentuk dihidroksi-PAH yang merupakan substrat untuk membuka cincin melalui proses didehidrogenasi. Enzim monooksigenase yang diberi satu molekul oksigen juga akan mampu mendegradasi $\mathrm{PAH}$ dan membentuk arene oksida. 


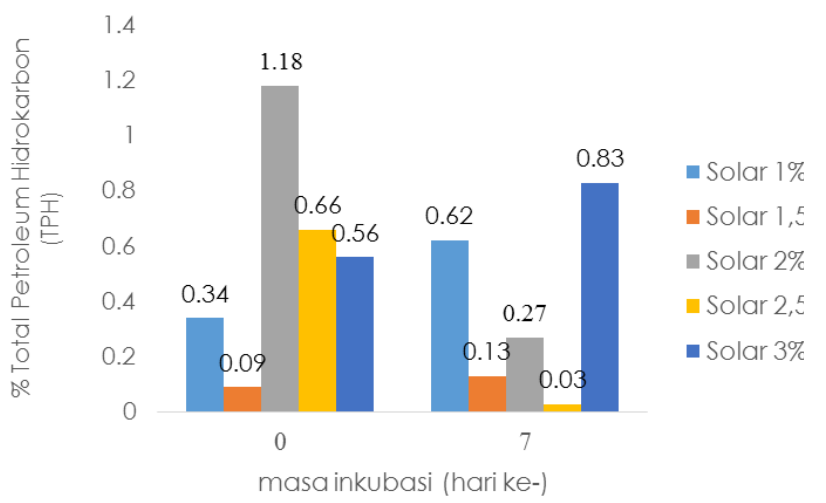

(a)

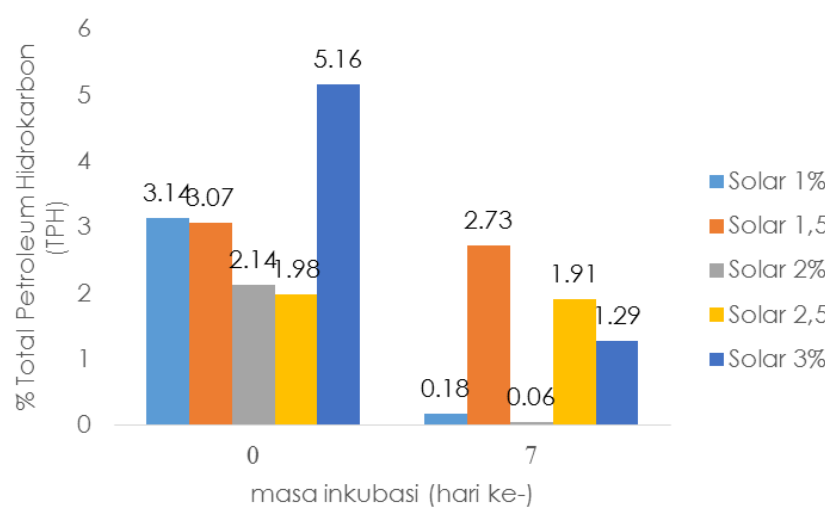

(b)

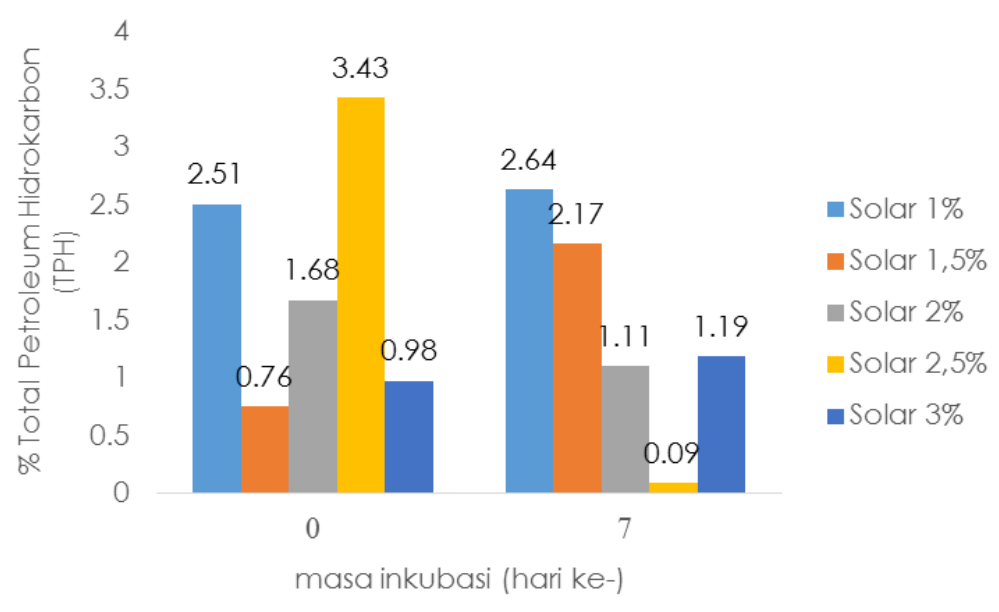

(c)

Gambar 3. Nilai \% Total Petroleum Hidrokarbon (TPH) (a).Kontrol (b).Konsorsium Indigenous (c).Konsorsium Bittern

Molekul tersebut dimanfaatkan oleh bakteri sebagai sumber nutrisi untuk energi dan pertumbuhan (Hasyimuddin et al., 2016).

\section{KESIMPULAN}

Berdasarkan penelitian yang telah dilakukan dapat disimpulkan bahwa diperoleh 4 jenis bakteri (BI.1, BI.2, BI.3, dan BI.4) dari perairan pelabuhan kamal. Kemampuan degradasi tertinggi oleh konsorsium indigenous yaitu pada perlakuan $3 \%$ dengan penurunan \% total petroleum hidrokarbon (TPH) sebesar 3,87, sedangkan konsorsium bittern nilai degradasi tertinggi terdapat pada perlakuan solar 2,5\% dengan penurunan \% total petroleum hidrokarbon (TPH) sebesar 3,34. Penelitian lanjutan terkait identifikasi bakteri dan uji statistik perlu dilakukan guna mengembangkan penelitian sebelumnya.

\section{DAFTAR PUSTAKA}

Andhini, N., Nursyirwani., \& S, Nedi. 2018. Isolasi Bkteri Pendegradasi Minyak dari Perairan Sekitar Pelabuhan Bengkalis Provinsi Riau. Jurnal Perikanan dan Kelautan, 23(1):15-20.

Bhaktinagara, R.A., Agung, S., \& Budi, R. 2015, Biodegradasi Senyawa Hidrokarbon oleh Strain Bacillus cereus (VIC) pada Kondisi Salinitas yang Berbeda. Jurnal Biologi, 3(4):62-71.

Charlena., Mas'Ud, Z.A., Mohamad, Y., Ahmad, S., \& Joko, G.T. 2011 . Biodegradasi Limbah Minyak Berat Menggunakan Isolat 
Tunggal dan Campuran dengan Penambahan Alkibenzena sulfonat Linear. Seminar Nasional Kimia Terapan Indonesia. Serpong. 24 Mei. 182-189.

Elvira, I., Sri, W., \& Nur, A. 2016. Karakterisasi Sifat Biokimia Isolat Bakteri Asam Laktat yang Dihasilkan dari Proses Fermentasi Wikau Maombo. Jurnal Sains dan Teknologi Pangan, 2(1):121-124.

Hafiluddin. 2011. Bioremediasi Tanah Tercemar Minyak dengan Teknik Bioaugmentasi dan Biostimulasi. Jurnal Embryo, 8(1):47-52.

Hasyimuddin., M. Natsir, D., \& M. Farid, S. 2016. Isolasi Bakteri Pendegradasi Minyak Solar dari Perairan Teluk Pare-pare. Jurnal IImiah Biologi, 1(4):41-46. doi : 10.24252/ bio.v4i1.1119

Ismail, H. E., Nursiah, L. N., \& Seniwati, D. 2015. Isolasi Bakteri Pendegradasi Senyawa Pirendari Perairan Pelabuhan Paotere. Jurnal Techno, 2(1):1-7.

Junaedi, A. S., Riana, F., Sari, H.C.P.S., Witria. \& Zainuri, M. 2020. Kualitas Daging Ikan Kurisi (Nemipterus japonius) Hasil Tangkapan Nelayan di Pelabuhan Perikanan Branta, Pamekasan. Jurnal Pengolahan Hasil Perikanan Indonesia, 23(2): 303-319

Mijaya, M.R.S., Nur, A.Y., Ardiansyah., \& Nurhayani, H.M. 2019. Isolasi dan Seleksi Bakteri Pendegradasi Solar dari Pelabuhan Penyeberangan Kendari Wawonii, Sulawesi Tenggara. Jurnal Penelitian Biologi, 2(6):995-1006. doi: 10.33772/biowallacea.v6i2.8825

Mudatsir. 2007. Faktor-faktor yang Mempengaruhi Kehidupan Mikroba dalam Air. Jurnal Kedokteran Syiah Kuala, 1 (7): 23-29.

Nababan, B. 2008. Isolasi dan Uji Potensi Bakteri Pendegradasi Minyak Solar dari Laut Belawan. Tesis. Sekolah Pascasarjana Universitas Sumatera Utara, Medan.

Nasikhin, R, \& M. Shovitri. 2013. Isolasi dan Karakterisasi Bakteri Pendegradasi Solar dan Bensin dari Perairan Peabuhan Gresik. Jurnal Sains dan Seni Pomits, 2(2):84-88.

Nugroho, A. 2007. Dinamika Populasi Konsorsium Bakteri Hidrokarbonoklastik:
Studi KasusBiodegradasi Hidrokarbon Minyak Bumi Skala Laboratorium. Jurnal Ilmu Dasar, 1 (8):13-23.

Nurjanah, I., Maulidiyah., \& M. Munir. 2020. Potensi Degradasi Minyak Soar oleh BakteriHidrokarbonoklastik di Perairan Pelabuhan Tanjung Perak. Journal of Marine Resources and Coastal Management, 1(1):31-38.

Prayitno, J., Amalia, M., \& Esi, L. 2010. Degradasi Minyak Mentah dan Solar oleh Konsorsium Mikroba Asal Pertambangan Minyak Cepu. Jurnal Ecolab, 2(4):55-96. doi : 10.20886/jklh.2010.4.2.81-88

Puspitasari, I., Agus, T., \& Jusup, S. 2020. Eksplorasi Bakteri Pendegradasi Minyak dari Perairan Pelabuhan Tanjung Mas, Semarang. Journal of Marine Research, 3(9):281-288.

Ristiati, N. P, Sanusi, M, \& I M.G.P. Putra. 2016. Uji Kemampuan Degradasi Minyak Solar Oleh Konsorsium Bakteri Hasil Preservasi dengan Kombinasi Metode Liofilisasi dan Metode Gliserol. Prosiding Seminar Nasional MIPA. 258-267.

Safrida, Y.D., Cut, Y., \& Cut, N.D. 2012. Isolasi dan Karakterisasi Bakteri Berpotensi Probiotik pada Ikan Kembung (Rastrelliger sp.). Jurnal Depik, 1(3):200203.

Sopiah, N., Avi, N.O., Susi, S., Fuji, S., \& Dwindrata, B.A. 2011. Isolasi dan Identifikasi Bakteri Pendegradasi Hidrokarbon yang Berasal dari Tanah Tercemar Minyak Bumi. Jurnal Teknologi Lingkungan, 3(2):291-298. doi : 10.29122/ jtl.v12i3.1238

Sulistyono. 2013. Dampak Tumpahan Minyak (Oil Spill) di Perairan Laut pada Kegiatan Industri Migas dan Metode Penanggulangannya. Forum Teknologi, 3(1):49-57.

Utomo, Y., Priyono, B., \& Ngabekti, S. 2013. Saprobitas Perairan Sungai Juwana Berdasarkan Bioindikator Plankton. Unnes Journal of Life Science, 2(1):28-35.

Wahyuni, R. M., Arman, S., Mahdi, A., Erina., M. Hasan., \& Zainuddin. 2018. Isolasi dan Identifikasi Bakteri Enterik Patogen pada Badak Sumatera (Dicerorhinus sumatrensis) di Suaka Rhino Sumatera (SRS), Taman Nasional Way Kambas (TNWK), Lampung. 
Jurnal IImiah Mahasiswa Veteriner, 4(2):474487.

Yolantika, H., Periadnadi., \& Nurmiati. 2015. Isolasi Bakteri Pendegradasi Hidrokarbon di Tanah Tercemar Lokasi Perbengkelan Otomotif. Jurnal Biologi Universitas Andalas, 4(2):153-157. 